\title{
Macrophage Migration Inhibitory Factor (MIF)-Based Therapeutic Concepts in Atherosclerosis and Inflammation
}

\author{
Dzmitry Sinitski ${ }^{1, *}$ Christos Kontos ${ }^{2, *}$ Christine Krammer ${ }^{1, *}$ Yaw Asare ${ }^{3}$ Aphrodite Kapurniotu ${ }^{2, * *}$ \\ Jürgen Bernhagen ${ }^{1,4,5, * *}$
}

${ }^{1}$ Department of Vascular Biology, Institute for Stroke and Dementia

Address for correspondence Jürgen Bernhagen, PhD, Chair of Vascular Biology, Institute for Stroke and Dementia Research (ISD), Research (ISD), Klinikum der Universität München (KUM), LudwigMaximilians-University (LMU), Munich, Germany

${ }^{2}$ Division of Peptide Biochemistry, Technische Universität München (TUM), Freising, Germany

${ }^{3}$ Department of Translational Medicine, Institute for Stroke and Dementia Research (ISD), Klinikum der Universität München (KUM), Ludwig-Maximilians-University (LMU), Munich, Germany

${ }^{4}$ Munich Heart Alliance, Munich, Germany

${ }^{5}$ Munich Cluster for Systems Neurology (SyNergy), Munich, Germany Klinikum der Universität München (KUM), Ludwig-MaximiliansUniversity (LMU) Munich, Feodor-Lynen-Straße 17, 81377 Munich, Germany (e-mail: juergen.bernhagen@med.uni-muenchen.de).

Aphrodite Kapurniotu, PhD, Division of Peptide Biochemistry, Technische Universität München (TUM), Emil-Erlenmeyer-Forum 5, 85354 Freising, Germany (e-mail: akapurniotu@wzw.tum.de).

Thromb Haemost 2019;119:553-566.

\begin{abstract}
Chemokines orchestrate leukocyte recruitment in atherosclerosis and their blockade is a promising anti-atherosclerotic strategy, but few chemokine-based approaches have advanced into clinical trials, in part owing to the complexity and redundancy of the chemokine network. Macrophage migration inhibitory factor (MIF) is a pivotal mediator of atherosclerotic lesion formation. It has been characterized as an inflammatory cytokine and atypical chemokine that promotes atherogenic leukocyte

Keywords

- MIF

- chemokine receptor

- atypical chemokine

- small molecule drug compound

- peptide

- antibody recruitment and lesional inflammation through interactions with the chemokine receptors CXCR2 and CXCR4, but also exhibits phase-specific CD74-mediated cardioprotective activity. The unique structural properties of MIF and its homologue MIF-2/DDT offer intriguing therapeutic opportunities including small molecule-, antibody- and peptide-based approaches that may hold promise as inhibitors of atherosclerosis, while sparing tissue-protective classical chemokine pathways. In this review, we summarize the pros and cons of anti-MIF protein strategies and discuss their molecular characteristics and receptor specificities with a focus on cardiovascular disease.
\end{abstract}

\section{Introduction}

Atherosclerosis is a chronic inflammatory disease of our arteries that is characterized by the development of lipid-

\footnotetext{
*Contributed equally.

** Shared last authorship and correspondence.
}

rich inflamed plaques in the vessel wall. Lesion progression and plaque rupture may result in detrimental cardiovascular events such as acute myocardial infarction and ischaemic stroke, ${ }^{1,2}$ the leading causes of death worldwide. ${ }^{3}$ Influenced by genetic and environmental risk factors such as hyperlipidaemia, atherosclerosis is initiated by endothelial dysfunction, followed by an accumulation of oxidized low-density lipoproteins (oxLDLs) and an inflammatory cell infiltrate received

October 1, 2018

accepted after revision

December 21, 2018 (c) 2019 Georg Thieme Verlag KG Stuttgart · New York
DOI https://doi.org/ 10.1055/s-0039-1677803. ISSN 0340-6245. 
dominated by monocytes and $\mathrm{T}$ cells into the atherogenic vessel wall. Infiltrating monocytes differentiate into macrophages and lipid-laden foam cells. Lesion progression also involves vascular smooth muscle cell (VSMC) proliferation, necrotic core formation and wall remodelling that may eventually lead to plaque destabilization, rupture and thrombosis. ${ }^{4}$

These processes are mediated by inflammatory cytokines and chemokines at all stages. Some 50 classical chemokines interact with $18 \mathrm{G}$-protein-coupled receptor (GPCR)-type chemokine receptors. This network is characterized by a high degree of redundancy and promiscuity and chemokines are divided into CC-, CXC-, $\mathrm{CX}_{3} \mathrm{C}$ - and $\mathrm{C}$-type sub-classes and correspondingly termed receptors. ${ }^{5,6}$

Due to their causal role in atherogenesis, anti-cytokine/chemokine approaches are pursued as therapeutic strategies to attenuate atherosclerosis. ${ }^{7}$ Several chemokine-blocking antibodies and chemokine receptor-inhibiting small molecule drug (SMD) compounds are in advanced pre-clinical testing and (early) clinical trial phases. ${ }^{7-11}$ Importantly, the

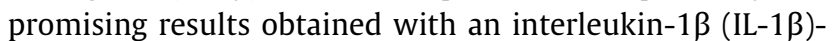
blocking antibody in the CANTOS trial have validated the inflammatory hypothesis in atherosclerosis and demonstrated the power of cytokine-based anti-inflammatory drugs in patients with established atherosclerotic disease. ${ }^{12}$

Macrophage migration inhibitory factor (MIF) is an inflammatory cytokine with chemokine-like characteristics and unique structural properties and is classified as a prototypical member of the emerging family of atypical chemokines (ACKs). ${ }^{13-16}$ ACKs lack the typical chemokine-fold and conserved $\mathrm{N}$-terminal cysteines of classical chemokines, ${ }^{6}$ but exhibit chemotactic activity and bind to classical chemokine receptors. ${ }^{16}$ MIF is up-regulated in human atherosclerotic lesions ${ }^{17}$ and its levels correlate with coronary artery disease (CAD). ${ }^{18,19}$ Mif gene deletion (Mif-KO) and antibody-based neutralization of MIF in experimental atherosclerosis suggest it is a major driver of atheroprogression during several stages of the disease. ${ }^{14,18}$

Here, we discuss molecular strategies to inhibit MIF and its structural homologue D-dopachrome tautomerase (DDT), also termed MIF-2, in atherosclerosis and other inflammatory diseases. We cover antibody-based strategies, small molecules directed at the unique MIF catalytic pocket around $\mathrm{N}$-terminal proline- 2 or at allosteric sites and emerging peptide-based approaches. The pros and cons of these strategies, potential side effects and envisaged receptor pathway specificities are compared.

\section{MIF is a Chemokine-Like Inflammatory Mediator that Promotes Atherosclerosis}

MIF is one of the first cytokines to be discovered. It was originally described in 1966 by John David as a soluble factor produced by human lymphocytes that was capable of inhibiting the random migration of macrophage-like cells out of capillary tubes, while earlier reports on myeloid cell migration even date back to $1932 .{ }^{15,20,21}$ MIF is a $12.5 \mathrm{kD}$ protein containing 114 amino acids that crystallizes as a trimer, but equilibria between monomers, dimers and trimers are observed under physiological solution conditions. ${ }^{22,23}$ Today, MIF is known as a pleiotropic inflammatory mediator that is structurally distinct from other cytokines, but shares structural homology with bacterial tautomerases/isomerases, suggesting evolutionary conservation. ${ }^{15,23,24}$ It is broadly expressed, but regulated secretion that occurs from semi-constitutive cytosolic stores by a p115-dependent nonconventional mechanism is predominantly seen in cells of the immune system as well as endothelial and tumour cells. ${ }^{15,25,26}$ MIF is the founding member of the MIF protein family that also comprises D-DT/MIF-2 and MIF-like orthologs in numerous species. MIF is an upstream regulator of the host innate and adaptive immune response, but-if dysregulated-it is a driver of inflammatory diseases as well as cardiovascular diseases including atherosclerosis. Contrary to its eponymous name, MIF has been classified as an ACK that, similar to arrest chemokines such as CXCL1/8, enhances atherogenic leukocyte chemotaxis and arrest. It has been suggested that inhibition of random macrophage migration as observed in the historic experiments, is likely to represent a desensitization effect as well-known for chemokines. ${ }^{14,16}$

Serving as an inflammatory, chemokine-like cytokine and upstream regulator of innate immunity, it is not unexpected that MIF has a key role in numerous inflammatory and autoimmune conditions, including septic shock, rheumatoid arthritis (RA), systemic lupus erythematosus, Crohn's disease, obesity, glomerulonephritis and inflammatory and allergic lung conditions (reviewed in Refs. ${ }^{15,27-30}$ ). Owing to the close mechanistic links between chronic inflammation and cancer, MIF also has been identified as a pro-tumorigenic factor in several tumour entities, enhancing cancer cell proliferation, promoting tumour angiogenesis and modulating anti-tumour immunity. ${ }^{15,31-34}$

Its chemokine-like and inflammatory properties render MIF a potent regulator of the atherogenic process. MIF expression is up-regulated in human and murine atherosclerotic lesions with peak levels observed in advanced plaques. ${ }^{17,19}$ It is not only up-regulated in the atherogenic endothelium and infiltrating leukocytes, but also in VSMCs and platelets following inflammatory stimulation. ${ }^{17,35,36}$ Antibody-mediated neutralization in Apoe - /- mice resulted in reduced lesional immune cell content and lowered levels of inflammatory mediators associated with atherosclerosis. ${ }^{37}$ Similarly, Mif-deficient Ldlr - /- mice showed reduced atherosclerotic plaque areas compared with controls. ${ }^{14,38}$ Targeting MIF with neutralizing antibodies resulted in significant plaque regression. ${ }^{14}$ The pro-atherogenic activity of MIF is predominantly mediated via noncognate interaction with the chemokine receptors CXCR2 and CXCR4, leading to monocyte and T cell recruitment, respectively. ${ }^{14}$ This is accompanied by an up-regulation of adhesion molecules like intercellular adhesion molecule 1 and release of atherogenic chemokines such as CCL-2.39,40 Moreover, MIF stimulates oxLDL uptake to promote foam cell formation. Foam cells undergo apoptosis and form a necrotic core surrounded by a fibrous cap. ${ }^{41}$ MIF is associated with plaque instability as it induces matrix degradation through 
matrix metalloproteinases, followed by fibrous cap thinning resulting in plaque rupture. ${ }^{42} \mathrm{MIF}$ also promotes intra-plaque inflammation by stimulating macrophages to secrete inflammatory mediators such as tumour necrosis factor (TNF)- $\alpha$ or IL- $1 \beta .{ }^{43}$ The role of MIF- 2 in chronic atherogenesis is subject to current investigations.

Pro-atherogenic effects of MIF are supported by observational clinical studies in CAD patients. For the G/C singlenucleotide polymorphism rs755622 at position -173 , a higher susceptibility to develop CAD has been observed for C allele carriers. ${ }^{44-46}$ Moreover, the MIF gene features a tetranucleotide CATT repeat polymorphism ('the CATT $_{5-8}$ microsatellite') at position -794 that was initially identified in RA patients and controls gene expression from the MIF promoter. ${ }^{47} \mathrm{CATT}_{7}$ or $\mathrm{CATT}_{\text {non-5 }}$ MIF high expressers show an increased severity of coronary artery atherosclerosis and patients carrying the rs755622 $\mathrm{C}$ allele and $\mathrm{CATT}_{7} / \mathrm{C}$ haplotype are more prone to develop CAD. ${ }^{48}$ This correlates with associations between plasma MIF and CAD, for example, in acute coronary syndrome (ACS). ${ }^{18,19,49,50}$ Moreover, MIF plasma levels were found to be elevated in a high proportion of ST-elevation myocardial infarction (STEMI) patients, were suggested to be an early marker of acute STEMI, and STEMI patients with high admission MIF level experienced a poorer recovery of cardiac function and worse long-term adverse outcomes. ${ }^{19,51-53}$ Moreover, the role of MIF in myocardial ischaemia/reperfusion injury (MI/RI) has become apparent from clinical studies in cardiac surgery patients and mouse models. The cardiac surgery procedure recapitulates the ischaemic and reperfusion stress seen in myocardial infarction patients, but in contrast to the endogenously occurring myocardial infarction pathology in STEMI patients subjected to percutaneous coronary intervention, the onset of inflammation and oxidative injury in cardiac surgical patients is predictable as cardiac surgery with the cardioplegia-induced myocardial arrest, assistance of cardiopulmonary bypass and the following myocardial reperfusion, reproducibly elicits an ischaemia-reperfusion sequelae. Intriguingly, the increase in peri-operative MIF levels in cardiac surgery patients, as well as ratios of MIF and its soluble receptor CD74 (sCD74), suggest a cardioprotective role of MIF in the ischaemic and early reperfusion phase after myocardial infarction. ${ }^{54-56}$ In fact, cardioprotection by MIF in MI/RI is confirmed in numerous mouse models. ${ }^{19,57-62}$ Along the same lines, the myocardium-specific conditional knockout of $D$-dt/Mif-2 exacerbates MI/RI, while MIF-2 levels positively correlated with worse outcome in cardiac surgery patients. ${ }^{54,63}$ Interestingly, experimental models addressing the later postischaemic phase indicated that the role of MIF in cardiac ischaemia is complex, with phase-dependent cardioprotective and exacerbating effects observed. ${ }^{57-59,61,64} \mathrm{MIF}$ is initially released by ischaemic cardiomyocytes or endothelial cells and triggers a cardioprotective autocrine/paracrine signalling response in cardiomyocytes. Here, MIF not only binds to the chemokine receptors CXCR2 and CXCR4, but also to $\mathrm{CD} 74$, the surface-expressed form of the major histocompatibility complex (MHC) class II invariant chain, which serves a secondary function as a high-affinity MIF receptor. ${ }^{65}$
Cardiac-derived-first wave-MIF interacts with cardiomyocyte-expressed CD74 in the ischaemic and early reperfusion phase of MI/RI to trigger cardioprotective signalling through adenosine monophosphate (AMP) kinase metabolic reprogramming, an increase in glucose uptake via membrane translocation of GLUT4 and the AKT and extracellular-signal-regulated kinase survival pathways, while pro-apoptotic c-Jun N-terminal kinase signalling is attenuated. ${ }^{58,60}$ MIF-2 also mediates cardioprotection in this phase via CD74/AMPactivated protein kinase (AMPK) signalling. ${ }^{63}$ MIF/CD74/ AMPK-mediated ischaemic recovery is impaired in the senescent heart, suggesting that this protective mechanism could be dampened in aged CHD patients. ${ }^{66}$ MIF's antioxidant capacity that is based on its redox-active CXXC motif and that it shares with thiol-protein oxidoreductases such as thioredoxin ${ }^{67}$ also contributes to cardioprotection in the early phase of MI/RI stress. ${ }^{57,59,62}$ In contrast, MIF's role in the later phase of MI/RI stress in the heart is an 'inflammatory' one that is mediated by CXCR2/CXCR4-dependent recruitment of monocytes and neutrophils. Second wave MIF is additionally and abundantly produced by infiltrating inflammatory cells to amplify the inflammatory response. ${ }^{64}$ MIF's chemokine receptors serve a dual role in this phase with both protective (cardiomyocyte-expressed CXCR2/4) and pro-inflammatory (CXCR2/4 expressed on infiltrating myeloid cells) activity. ${ }^{68,69}$

\section{MIF Proteins and Their Receptors}

MIF binds to CXCR2 and CXCR4, representing non-cognate interactions between an ACK and classical chemokine receptors. MIF also binds to CD74, the surface-expressed form of invariant chain. All three receptors have important roles in atherosclerosis and cardiac disease (see above). Recent evidence also suggests engagement of CXCR7-mediated pathways by MIF. ${ }^{70-72}$

Binding of MIF to CXCR2 drives atherogenic recruitment of monocytes and neutrophils. ${ }^{14,73,74}$ Mechanistically, binding of MIF to CXCR2 is similar but not identical to that of the cognate ligand CXCL8 and requires an $\mathrm{N}$-like loop and pseudo-Glu-Leu-Arg (ELR) motif. ${ }^{16,74-76}$ While data are not yet available, it has been speculated that MIF-2 does not activate CXCR2 as it lacks the pseudo-(E)LR motif of MIF. MIF/ CXCR4 binding supports the recruitment of atherogenic T cells, ${ }^{14}$ but has also been implicated in cancer metastasis and endothelial progenitor cell recruitment. ${ }^{16}$ Recent evidence suggests an important role of the MIF/CXCR4 axis in B cell migration that may also contribute to the pro-atherogenic phenotype of MIF. ${ }^{70,77,78}$ CXCR4 is one of the few GPCRs for which an X-ray structure has been elucidated, ${ }^{79,80}$ and recent structure-activity studies (SAR) revealed that the MIF/CXCR4 interface involves an extended N-like loop of MIF, an ArgLeu-Arg (RLR) motif at position 87-89 and the N-terminal Pro- $2 .{ }^{81,82}$

Interestingly, both CXCR2 and CXCR4 are able to form receptor complexes with $\mathrm{CD} 74$, offering unexpected mechanistic options as to the fine-tuning of MIF-driven pathways in atherogenesis. In fact, MIF-mediated CXCR2/CD74 signalling 
has a role in atherogenic leukocyte recruitment, ${ }^{14,83}$ while CXCR4/CD74 complex formation and/or cross-talk is necessary for MIF-driven $B$ cell migration responses and elicits downstream ZAP-70 signalling. ${ }^{77,84}$

Intracellular CD74/invariant chain acts as an MHC II chaperone facilitating antigen loading to class II complexes in the endoplasmic reticulum. ${ }^{85}$ However, CD74 may be also expressed in class II-negative cells, that is, upon inflammatory stimulation, and exhibits a major role as cytokine receptor for MIF and MIF-2. ${ }^{65,86}$ MIF and MIF-2 bind to the extracellular domain of CD74, but as CD74 exhibits a short cytoplasmic domain, signal transduction necessitates accessory molecules such as CD44 or CXCR2/4. ${ }^{14,16,65,87}$ A soluble form of CD74 (sCD74) was identified in patients with autoimmune liver disease, ${ }^{88}$ and as outlined above, evidence from cardiac surgery patients suggests that circulating sCD74 levels correlate with better outcome. ${ }^{54,56}$ sCD74-derived strategies could thus represent interesting MIF-targeting approaches in the future.

\section{Antibody-Based Anti-MIF Strategies}

Antibody-based anti-cytokine/-chemokine strategies are promising therapeutic approaches in inflammatory and cardiovascular diseases. Prominent examples are the IL-1 $\beta$ antibody canakinumab, which was shown in the CANTOS trial to reduce vascular inflammation accompanied by a lower rate of recurrent cardiovascular events, ${ }^{12}$ the antiTNF- $\alpha$ antibody infliximab, successfully used in RA, ${ }^{89}$ and numerous chemokine antibodies such as anti-CCL2 (CNT0888/ABN912), which are in phase 1 and 2 clinical studies for various inflammatory conditions and cancer. ${ }^{90,91}$ Chemokine antibodies such as anti-CCL2 have been efficacious in pre-clinical models of atherosclerosis, ${ }^{7}$ suggesting their potential in CAD patients.

Neutralization of MIF by blocking antibodies has improved disease exacerbation in numerous pre-clinical inflammation models including atherosclerosis. ${ }^{18,37,92,93}$ The most widely used antibody has been the monoclonal NIH/IIID.9, which was raised against full-length mouse MIF. It was initially tested in immunologically induced kidney disease ${ }^{94}$ and has been demonstrated to potently block disease progression in numerous inflammatory, autoimmune and cardiovascular conditions. ${ }^{14,16,18,19,37,95}$ The epitope recognized by NIH/IIID.9 has not been characterized, but it has been suggested that it recognizes a solvent-exposed region of MIF in the middle part of the sequence, ${ }^{95}$ similar to mAb clone $1 \mathrm{C} 10$ (Bernhagen et al, unpublished), but unlike clone F11, which blocks cecal ligation and puncture-induced sepsis and is directed against the $\mathrm{N}$ terminal of murine MIF. ${ }^{96}$

From the existing anti-MIF antibodies successfully tested in pre-clinical inflammation, cancer and atherosclerosis models, only the MIF antibody imalumab has so far advanced into phase 1/2a clinical trials (NCT01765790) against colorectal cancer and lupus nephritis. ${ }^{97}$ Imalumab has an anti-inflammatory capacity as it reduces circulating TNF- $\alpha$, monocyte chemoattractant protein-1 and IL-6, and attenuates disease progression in mouse models of glomerulonephritis and cancer. Based on biochemical and immunochemical experiments, it was suggested that this antibody recognizes an oxidized form of MIF with the oxidoreductase motif of MIF trapped in an oxidized state, and that Cys-81 serves as a molecular redox switch between the latent reduced form of MIF and its oxidized state. $^{93,98,99}$ While the antibody was reported to detect an oxidized MIF species termed 'oxMIF' in tumour tissue from patients with colorectal, pancreatic, ovarian and lung cancer, ${ }^{100}$ the claim that oxMIF is the pathophysiologically relevant MIF species appears speculative and convincing evidence that imalumab targets pathogenic oxMIF species is missing. ${ }^{67,95}$

MIF-2/D-DT shares with MIF a pronounced pro-inflammatory activity profile and has been reported to promote endotoxaemia, adipose tissue inflammation and tumorigenesis similar to MIF. As discussed, MIF-2 also is involved in early cardioprotection after $\mathrm{MI} / \mathrm{RI}$ and regulates kidney regeneration, but its role in atherosclerosis has not been studied. $^{19,63,86,101-103}$ Functional studies on MIF-2 have capitalized on Mif-2 gene deletion ${ }^{63}$ and a neutralizing antibody. ${ }^{86}$ While this polyclonal antibody shows good blocking potency in pre-clinical models, ${ }^{86}$ a monoclonal antibody has not been published.

Cytokine/chemokine pathways may be targeted by neutralization of the ligand or may rely on strategies to block the receptor binding site of the ligand and/or receptor signalling. Antibodies against CD74 recapitulate many of the effects seen with neutralizing MIF antibodies, but differences have also been noted. As both MIF and MIF-2 bind to CD74, these may be due to MIF-2-triggered responses that are inhibited by anti-CD74 but not anti-MIF strategies. No other endogenous ligands than MIF or MIF-2 have been identified for CD74. Yet, the blocking phenotype of anti-CD74 may differ from a combined anti-MIF/anti-MIF-2 strategy due to class II-associated functions of endolysosomal-expressed CD74/invariant chain. In fact, specific peptide-based strategies have been developed to block class II-associated functions of CD74 in multiple sclerosis ${ }^{104-107}$ (see below).

A neutralizing CD74 mAb has shown potent inhibitory activity in haematologic cancers such as chronic lymphocytic leukaemia (CLL) and multiple myeloma. ${ }^{108,109}$ One of these mAb clones, a humanized anti-CD74 monoclonal termed milatuzumab/hLL1, is in clinical trials for CLL and multiple myeloma treatments. However, although gene deletion of CD74 significantly attenuates atherosclerosis in atherogenic Ldlr - / - mice ${ }^{110}$ and although CD74 serves as an accessory molecule in MIF-driven CXCR2/4-mediated leukocyte recruitment responses, ${ }^{14}$ neutralizing CD74 antibodies have not been studied in atherosclerosis. It should be emphasized that antiCD74 strategies may be intrinsically limited regarding their translational potential in atherosclerotic disease due to cardiac protection mediated via the CD74/AMPK pathway in cardiomyocytes following ischaemic stress. ${ }^{58}$ It rather seems that MIF-based strategies in cardiovascular disease should aim at sparing CD74-mediated pathways. ${ }^{19}$

CXCR2 and CXCR4 are bona fide GPCRs, but antibody development against GPCRs has been delayed. In fact, of the numerous GPCR-modulating agents available, most are small molecules or peptides. Recently, the first GPCR- 
directed antibody (erenumab), an antibody against calcitonin gene-related peptide receptor, was Food and Drug Administration (FDA)-approved for treatment of migraine. ${ }^{111}$ Meanwhile, the development of additional anti-GPCR antibodies including antibodies against CC and CXC chemokine receptors is underway. ${ }^{111}$

CXCR4 antibodies are in advanced clinical trials for haematologic malignancies, ${ }^{112}$ and anti-CXCR4 SMDs such as the bicyclam plerixafor/AMD3100 which promotes CXCR4-dependent haematopoietic stem cell egress from bone marrow is clinically used in autologous stem cell transplantation of cancer patients. ${ }^{113}$ Nevertheless, anti-CXCR4 antibody strategies as a means to block MIF-driven pathogenic pathways in atherosclerosis should be pursued with caution. The CXCR4/CXCL12 axis has important homeostatic functions in development and physiology that render generalized anti-CXCR4 strategies difficult. Moreover, disrupting the CXCL12/CXCR4 axis in a mouse model of atherosclerosis promoted lesion formation through dysbalanced neutrophil homeostasis, ${ }^{114}$ and a recent study demonstrated a potent atheroprotective effect of vascular CXCR4 via maintaining arterial integrity, endothelial barrier function and preserving contractile VSMC functions. ${ }^{115}$

Cxcr2 gene deficiency reduces the progression of advanced atherosclerosis in mice and, in fact, CXCR2 has been one of the first chemokine receptors implicated in atherogenesis. ${ }^{116,117}$ CXCR2 also is involved in MIF-elicited atherogenic monocyte and neutrophil recruitment, ${ }^{14,16,75}$ emphasizing the significance of the MIF/CXCR2 axis in leukocyte arrest and atherogenesis. Moreover, anti-MIF antibodies proved superior to anti-CXCL1 (and anti-CXCL12) in an atherosclerosis regression model. ${ }^{14}$ An anti-CXCR2 anti- body therapy is considered a translatable strategy in solid cancer, for example, through improving the efficacy of checkpoint blockade by preventing trafficking of myeloidderived suppressor cells to the tumour site ${ }^{118}$ and antiCXCR2 strategies are pursued in various clinical trials, ${ }^{119}$ including ACS. ${ }^{120}$ An anti-CXCR2 bi-paratopic nanobody is in phase I development for the treatment of inflammation. ${ }^{111}$ Antibody strategies for epitopes specifically targeting MIF/CXCR2 receptor pathways in vascular inflammation and atherosclerosis have not been pursued.

- Table 1 summarizes published antibody-based strategies directed at MIF proteins and/or their receptors.

\section{Small Molecule Drug-Based Anti-MIF Strategies}

MIF proteins are structurally unique among cytokines/ chemokines in harbouring a conserved catalytic tautomerase cavity that contains the unusually acidic Pro-2 residue. This offers the opportunity to target pathogenic activities of MIF by small molecule approaches. Capitalizing on efficient drug discovery pipelines including in silico and high-throughput screening, numerous anti-MIF SMDs have been identified that bind into or modulate the tautomerase pocket of MIF and/or MIF-2/D-DT by covalent or noncovalent mode.

Small molecule MIF inhibitors have been compiled in several recent review articles. ${ }^{24,95,121,122}$ Here, we discuss some of these compounds with a focus on their potential utility in atherosclerosis. - Table 2 summarizes the key features of these inhibitors.

Table 1 Antibodies targeting MIF proteins or their receptors

\begin{tabular}{|c|c|c|c|}
\hline Antibody & Target/Antigen & $\begin{array}{l}\text { Application/Utility in athero- } \\
\text { sclerosis }\end{array}$ & References \\
\hline $\mathrm{NIH} / \mathrm{IIID} .9$ (mAb) & Mouse MIF (full-length) & $\begin{array}{l}\text { Research and pre-clinical models; } \\
\text { blocks atherogenic effects of MIF }\end{array}$ & $14,37,94$ \\
\hline $\begin{array}{l}\text { Imalumab (Bax69) (humanized } \\
\text { mAb) }\end{array}$ & Oxidized form of human MIF & $\begin{array}{l}\text { Phase Ila trial for metastatic } \\
\text { colorectal cancer }\end{array}$ & 97 \\
\hline BaxB01, BaxG03, BaxM159 & $\begin{array}{l}\text { Oxidized form of human, mouse or } \\
\text { rat MIF }\end{array}$ & Research and pre-clinical models & $93,98-100,163$ \\
\hline $\begin{array}{l}\text { NbE10-NbAlb8-NbE10 (half-life- } \\
\text { extended nanobody) }\end{array}$ & Human and mouse MIF & $\begin{array}{l}\text { Research and pre-clinical sepsis } \\
\text { model }\end{array}$ & 164 \\
\hline Anti-MIF-2/D-DT & Mouse MIF-2/D-DT (full-length) & Research and pre-clinical models & 86 \\
\hline Milatuzumab & CD74 & Multiple myeloma, NHL, CLL & 108,165 \\
\hline $\begin{array}{l}\text { i-bodies (AM3-114, AM4-272, } \\
\text { AM3-523; single domain } \\
\text { antibody) }\end{array}$ & CXCR4 & Research and pre-clinical models & 166 \\
\hline MEDI3185 & CXCR4 & Research and pre-clinical models & 112 \\
\hline $\begin{array}{l}\text { Anti-CXCR2 bi-paratopic } \\
\text { nanobody }\end{array}$ & CXCR2 & $\begin{array}{l}\text { Pre-clinical models and phase I } \\
\text { clinical trial }\end{array}$ & 111 \\
\hline MAB331 & CXCR2 & Research and pre-clinical models & 14,167 \\
\hline${ }^{*} \mathrm{sCD74}$ & Human and mouse MIF & Research and pre-clinical models & $56,65,88$ \\
\hline
\end{tabular}

Abbreviations: CLL, chronic lymphocytic leukaemia; D-DT, D-dopachrome tautomerase; MIF, migration inhibitory factor; NHL, non-Hodgkin lymphoma.

Note: ${ }^{\text {s }} \mathrm{CD} 74$ is not an antibody, but the soluble ectodomain of MIF receptor CD74. 
Table 2 Small molecules targeting MIF proteins or their receptors

\begin{tabular}{|c|c|c|c|c|}
\hline $\begin{array}{l}\text { Small molecule drug (SMD) } \\
\text { inhibitor }\end{array}$ & Target/Binding mode & $K_{i}$ & $\mathrm{IC}_{50} / \mathrm{EC}_{50}$ & References \\
\hline $\begin{array}{l}\text { NAPQI } \\
\text { (N-acetyl-p-benzoquinone imine) }\end{array}$ & $\begin{array}{l}\text { MIF } \\
\text { Pro-2 } \\
\text { Covalent }\end{array}$ & $\mathrm{N} / \mathrm{A}$ & $\mathrm{IC}_{50}($ dopachrome $)=40 \mu \mathrm{M}$ & 131,168 \\
\hline $\begin{array}{l}\text { 4-IPP } \\
\text { (4-iodo-6-phenylpyrimidine) }\end{array}$ & $\begin{array}{l}\text { MIF/D-DT } \\
\text { Pro-2 } \\
\text { Covalent }\end{array}$ & $\mathrm{N} / \mathrm{A}$ & $\mathrm{IC}_{50}(\mathrm{HPP})=0.2-0.5 \mu \mathrm{M}$ & 169,170 \\
\hline $\begin{array}{l}\text { ISO-1 } \\
\text { (4,5-Dihydro-3-(4-hydroxyphe- } \\
\text { nyl)-5-isoxazoleacetic acid methyl } \\
\text { ester) }\end{array}$ & $\begin{array}{l}\text { MIF } \\
\text { Tautomerase site } \\
\text { Competitive }\end{array}$ & $\begin{array}{l}K_{i}(\mathrm{HPP})= \\
24 \mu \mathrm{M}\end{array}$ & $\begin{array}{l}\mathrm{IC}_{50} \text { (dopachrome) } \\
=7 \mu \mathrm{M}\end{array}$ & 130,171 \\
\hline $\begin{array}{l}\text { SCD-19 } \\
\text { isocoumarin }\end{array}$ & $\begin{array}{l}\text { MIF } \\
\text { Tautomerase site } \\
\text { Competitive }\end{array}$ & Not tested & $100 \%$ inhibition at $100 \mu \mathrm{M}$ & 172,173 \\
\hline $\begin{array}{l}\text { 4-CPPC } \\
\text { (4-(3-Carboxyphenyl)-2,5-pyridi- } \\
\text { nedicarboxylic acid) }\end{array}$ & $\begin{array}{l}\text { MIF-2/D-DT } \\
\text { C-terminus } \\
\text { V114 - L118 } \\
\end{array}$ & $\begin{array}{l}K_{i}(\mathrm{HPP})= \\
33 \pm 0.7 \mu \mathrm{M}\end{array}$ & - & 125 \\
\hline $\begin{array}{l}\text { Ebselen } \\
\text { (2-Phenyl-1,2-benzisoselenazol-3 } \\
\text { (2H)-one) }\end{array}$ & $\begin{array}{l}\text { MIF trimer } \\
\text { Cys- } 81 \\
\text { Covalent }\end{array}$ & $\begin{array}{l}K_{i} \\
(\mathrm{HPP})=0.57 \mu \mathrm{M}\end{array}$ & $\begin{array}{l}\mathrm{IC}_{50} \text { (dopachrome) } \\
=2.4 \mu \mathrm{M}\end{array}$ & 123 \\
\hline $\begin{array}{l}\text { p425 } \\
\text { 6,6'-[(3,3-Dimethoxy[1,1'-biphe- } \\
\text { nyl]-4,4'-diyl)bis(azo)]bis[4- } \\
\text { amino-5-hydroxy-1,3-napthalene- } \\
\text { disulphonic acid] }\end{array}$ & $\begin{array}{l}\text { MIF trimer } \\
\text { Allosteric }\end{array}$ & $K_{i}(\mathrm{HPP}) \leq 12 \mu \mathrm{M}$ & $\begin{array}{l}\mathrm{IC}_{50}(\mathrm{CD} 74 \text { inhibition }) \\
=0.81 \mu \mathrm{M}\end{array}$ & 124 \\
\hline $\begin{array}{l}\text { Ibudilast } \\
\text { AV411; 3-isobutyryl-2-isopropyl- } \\
\text { pyrazolo-[1,5-a]pyridine }\end{array}$ & $\begin{array}{l}\text { MIF } \\
\text { Tyr-37 } \\
\text { Allosteric }\end{array}$ & $\begin{array}{l}K_{i} \\
(\mathrm{HPP})=30.9 \mu \mathrm{M}\end{array}$ & - & $73,132,134$ \\
\hline $\begin{array}{l}\text { Plerixafor/AMD } 3100 \\
\text { (1-[4-(1,4,8,11-Tetrazacyclotetra- } \\
\text { dec-1-ylmethyl)phenyl]methyl)- } \\
\text { 1,4,8,11-tetrazacyclo-tetradecan }\end{array}$ & $\begin{array}{l}\text { CXCL12/CXCR4 } \\
\text { Orthosteric antagonist } \\
\text { MIF/CXCR4 } \\
\text { Partial allosteric } \\
\text { antagonist }\end{array}$ & - & $\begin{array}{l}\mathrm{IC}_{50}(\mathrm{CXCR} 4)=0.65 \mu \mathrm{M} \\
\mathrm{EC}_{50}(\mathrm{HIV} \text { entry }) \\
=0.4-2 \mu \mathrm{M}\end{array}$ & $\begin{array}{l}80,82,156,17 \\
4\end{array}$ \\
\hline $\begin{array}{l}\text { IT1t } \\
\text { Isothiourea-1t } \\
\text { 6,6-dimethyl-5H-imidazo[2,1-b] } \\
\text { [1,3]thiazol-3-yl)methyl N,N'- } \\
\text { dicyclohexylcarbamimidothioate }\end{array}$ & $\begin{array}{l}\text { CXCL12/CXCR4 } \\
\text { Orthosteric antagonist } \\
\text { MIF/CXCR4 } \\
\text { Partial allosteric } \\
\text { antagonist }\end{array}$ & - & $\begin{array}{l}\mathrm{IC}_{50}(\mathrm{gp} 120 \text { inhibition }) \\
=8 \mathrm{nM}\end{array}$ & $80,82,174$ \\
\hline $\begin{array}{l}\text { Reparixin } \\
\text { ( } \alpha R)-\alpha-\text {-methyl-4-(2-methylpro- } \\
\text { pyl)-N-(methylsulfonyl) } \\
\text { benzeneacetamide }\end{array}$ & $\begin{array}{l}\text { CXCL8/CXCR2 } \\
\text { Allosteric antagonist } \\
\text { MIF/CXCR2 (?) }\end{array}$ & - & $\begin{array}{l}\mathrm{IC}_{50} \text { (neutrophil } \\
\text { migration) }=1 \mathrm{nM}\end{array}$ & 174,175 \\
\hline
\end{tabular}

Abbreviations: D-DT, D-dopachrome tautomerase; HIV, human immunodeficiency virus; HPP, hydroxyphenylpyruvate; MIF, migration inhibitory factor.

Mechanistically, small molecule MIF inhibitors are classified into different categories: (1) competitive inhibitors that non-covalently bind into the cavity; (2) suicide inhibitors that covalently bind into the cavity; (3) allosteric inhibitors that disrupt the active-site through dissociation of the MIF trimer or an otherwise-induced conformational switch; and (4) allosteric inhibitors that prevent higher-order MIF oligomers. ${ }^{123,124}$ In addition, stabilizers of the MIF monomer have been proposed as inhibitors through prevention of re-association into trimer. ${ }^{123}$ These may only qualify as inhibitors of MIF/CD74 interactions, which involve trimeric MIF, whereas it has been assumed that the interaction between MIF and
CXCR2/CXCR4 is a function of the monomer. ${ }^{14}$ While most inhibitors have been developed against MIF, some also block MIF-2, although significant differences in $K_{i}$ and $\mathrm{IC}_{50}$ values have been noted. ${ }^{125} \mathrm{~A}$ recent study has identified a selective MIF-2 inhibitor that exhibits 13-fold higher binding to MIF-2 than MIF. ${ }^{125}$

The MIF tautomerase activity is highly conserved across kingdoms, but to date, physiological substrates in mammalians have not been identified, raising the possibility that it is an evolutionary remainder with no function in humans. Thus, it is now thought that by binding to the tautomerase site, these compounds induce conformational changes in MIF 
that subsequently alter its receptor-binding properties, ${ }^{82,126-129}$ and therefore 'indirectly' influence MIF activities.

The structures of the small molecule MIF inhibitors have been extensively reviewed. ${ }^{121,122}$ Briefly, with the iso-oxazoline compound ISO-1 serving as a reference MIF inhibitor in various inflammation models, ${ }^{130}$ they can be grouped into iso-oxazolines (examples: ISO-1, ISO-66, CPSI-1306), chromenes (examples: Orita-13, Kok-17), iminoquinones (example: $\mathrm{N}$-acetyl-p-benzoquinone imine), triazoles (example: Cisneros-3i), benzoxazolones (example: MIF098), pyrimidazoles (example: K664-1) and isocoumarins (e.g. SCD19). ${ }^{121,122,131}$ Allosteric MIF inhibitors encompass pyrazolopyridines (example: clinically used PDE4 inhibitor ibudilast), benzoisoselenazolones (example: anti-inflammatory drug ebselen) and azo compounds (example: p425 or Chicago Sky Blue 6b). ${ }^{73,123,124}$ Of note, ibudilast, which can cross the blood-brain barrier, was recently demonstrated in a phase II clinical trial in progressive multiple sclerosis, to be associated with slower progression of brain atrophy than placebo. ${ }^{132}$ Isothiocyanates, such as phenethyl isothiocyanate, are a reactive class of 'natural' MIF inhibitors that are present in appreciable amounts in broccoli and water cress. They covalently bind to the acidic Pro- 2 residue in the catalytic site of MIF, attenuate MIF antibody binding and inhibit inflammatory MIF activities in vitro, but have not yet been studied in atherosclerosis. ${ }^{123,133}$

While most of these compounds have not yet been studied in atherosclerosis-relevant test systems or pre-clinical models, some of them may hold promise as pathway-specific MIF inhibitors in atherogenesis. However, a 'black-andwhite' categorization into receptor-specific blockers appears too simplistic. For example, CD74 is a receptor mediating cardio- and tissue-protective MIF activities ${ }^{19,58}$; on the other hand, it drives pro-proliferative functions of MIF and can interact with the MIF chemokine receptors, which would be pro-atherogenic. ${ }^{14,70,109}$ CXCR4 mediates pro-atherogenic lymphocyte recruitment by $\mathrm{MIF}^{14,78}$ but also exhibits homeostatic and atheroprotective activities through CXCL12. ${ }^{115}$ Notwithstanding, it may be speculated that MIF trimerization inhibitors such as ebselen might have specificity for MIF/chemokine receptor pathways, while sparing MIF trimer-dependent CD74 signalling, ${ }^{123}$ which could lead to an overall atheroprotective effect. Ibudilast was found to block MIF/CD74 interactions in vivo by preventing astrocytederived MIF from interacting with CD74+ microglia during the colonization process of brain metastatic tumours resulting in reduced secondary brain tumour loads. ${ }^{134}$ Similarly, ISO-1 reduces MIF/CD74 binding albeit at relatively weak $\mathrm{IC}_{50}$ values, ${ }^{121}$ but interestingly, was recently also shown to partially interfere with MIF binding to CXCR4, opening up the possibility that certain MIF inhibitors may have utility in cardiovascular disease. However, given their small interaction surface, it remains questionable whether they would sufficiently differentiate between receptor pathways.

- Table 2 summarizes a selection of the developed small molecule MIF inhibitors from different structural classes and compares them to MIF chemokine receptor inhibitors.
To this end, AMD3100/Plerixafor and reparixin are established CXCR4 and CXCR2 inhibitors, respectively. AMD3100 also was shown to be a partial-allosteric-inhibitor of MIF/ CXCR4 signalling ${ }^{82}$; however, its preferential targeting of CXCL12/CXCR4 responses and its limited application window in autologous transplantation and human immunodeficiency virus (HIV), probably limits an efficacious usage as a specific anti-MIF compound. Reparixin has so far only been studied in MIF-dependent in vitro inflammatory assays. $^{135}$

\section{Peptide-Based Anti-MIF Strategies}

Peptide therapeutics are a powerful alternative to small molecule and antibody strategies with over 60 peptide drugs approved worldwide. The peptide therapeutic landscape has been reviewed in excellent recent reviews. ${ }^{136-138}$ Advantages of peptide-based inhibitors are: (1) good selectivity and potency, (2) good interaction surface coverage, (3) favourable safety and (4) comparatively low production costs due to standard synthesis protocols. On the other hand, they are prone to degradation and oxidation, but this can be improved by smart mimic chemistry. ${ }^{136,139}$

Even though peptide-based inhibitors have been pursued as potential therapeutics in atherosclerosis, for example, targeting lipid-regulating and inflammatory pathways such as apolipoproteins, nuclear factor-kappaB and the IL-4 receptor, ${ }^{140-142}$ peptide approaches targeting MIF-specific pathways are still in its infancies. Interestingly, a recent approach established designed peptide inhibitors that specifically disrupt pro-inflammatory CCL5-CXCL4 interactions, attenuating monocyte recruitment and reducing atherosclerosis. Targeting of CCL5-CXCL4 heteromers avoids side effects of generalized anti-CCL5 strategies which would compromise systemic host immunity, ${ }^{143,144}$ thus underscoring the potential of anti-chemokine peptide strategies.

Anti-MIF peptides have been examined in vitro and partially in pre-clinical disease models. Peptides targeting both the MIF/CD74 and MIF/chemokine receptor axes have been considered ( - Table 3 ); some of them are derived from mapping studies of the interfaces between MIF and its receptors.

MIF-derived peptides targeting interactions with CD74 have not yet been tested in disease models. This is probably due to the complex nature of the MIF/CD74 interaction surface, encompassing all three subunits of the MIF trimer and discontinuous epitopes within an MIF monomer. Nevertheless, a MIF epitope scan for reactivity of the CD74 ectodomain identified MIF peptide 79-86. This octapeptide was able to compete for biotinylated MIF binding to plate-bound CD74, ${ }^{88}$ indicating its principal inhibitory utility. A screening for antimelanoma peptides derived from conserved complementarity-determining region sequences of different immunoglobulins identified peptide C36L1, a 17-mer peptide that binds to CD74 on tumour-associated macrophages and dendritic cells and blocks immunosuppressive activities in melanoma models. $^{145,146}$ Other inhibitors that target the MIF-CD74 
Table 3 Peptides and peptide mimics targeting MIF proteins or their receptors

\begin{tabular}{|c|c|c|c|}
\hline Peptide inhibitor & Target/Binding mode & $\begin{array}{l}\text { Application/Utility in } \\
\text { atherosclerosis }\left(\mathrm{IC}_{50}\right)\end{array}$ & References \\
\hline $\begin{array}{l}\text { MIF }^{79-86} \text { (mouse) } \\
\text { LCGLLSDR }\end{array}$ & MIF/CD74 interface & $\mathrm{IC}_{50}=$ са. $2-3 \mu \mathrm{M}$ & 88 \\
\hline $\begin{array}{l}\text { MIF } \\
\text { LMAF-56 (human) } \\
\text { LMASSEP }\end{array}$ & $\begin{array}{l}\text { MIF } \\
\text { Competitive }\end{array}$ & $\mathrm{EC}_{50}=\mathrm{ca} \cdot 1-2 \mu \mathrm{M}$ & 76 \\
\hline $\begin{array}{l}\text { MIF }^{50-65} \text { (human) } \\
\text { FGGSSEPCALCSLHSI }\end{array}$ & $\begin{array}{l}\text { MIF } \\
\text { Competitive }\end{array}$ & Not determined & 176,177 \\
\hline $\begin{array}{l}\text { Conserved CDR peptide C36L1 } \\
\text { KSSQSVFYSSNNKNYLA-NH2 }\end{array}$ & CD74 & $\mathrm{IC}_{50}=$ upper $\mu \mathrm{M}$ range & 146 \\
\hline $\begin{array}{l}\text { RTL1000 } \\
\text { Class II-derived } \\
\text { Dra1 } 1 \text { 1MEVGWYRSPFSRVVHLYRNGK }\end{array}$ & $\begin{array}{l}\text { CD74 trimer } \\
\text { MIF/CD74 axis } \\
\text { Competitive }\end{array}$ & $\mathrm{IC}_{50}=$ nanomolar range & 107 \\
\hline $\begin{array}{l}\text { DR } 1 \text { 1-MOG-35-55 } \\
\text { Class II-derived } \\
\text { DR } 1 \text { 1MEVGWYRSPFSRVVHLYRNGK }\end{array}$ & $\begin{array}{l}\text { CD74 trimer } \\
\text { MIF/CD74 axis } \\
\text { Competitive }\end{array}$ & $\mathrm{IC}_{50}=$ nanomolar range & 104,107 \\
\hline $\begin{array}{l}\text { CXCL12(22-29) } \\
\text { KGVSLYR-K-RYSLVGK }\end{array}$ & CXCL12/CXCR4 axis & $\overline{\text { Not known }}$ & 178 \\
\hline $\begin{array}{l}\text { CXCL12a1-9[P2G] dimer } \\
\text { MNAKVVVVL-S-S-LVVVVKANM }\end{array}$ & CXCL12/CXCR4 axis & $\mathrm{IC}_{50}=2.6 \mu \mathrm{M}$ & 178 \\
\hline $\begin{array}{l}\text { Ac-Arg-Ala-[D-Cys-Arg-Phe-His-Pen]-COOH } \\
\text { Derivative of CXCL12 N-terminal }\end{array}$ & CXCL12/CXCR4 axis & $\mathrm{IC}_{50}=1.5 \mathrm{nM}$ & 158,159 \\
\hline $\begin{array}{l}\text { CVX15 } \\
\text { 16-residue cyclic peptide analogue of the horse- } \\
\text { shoe crab peptide polyphemusin }\end{array}$ & CXCR4 & Not known & 80 \\
\hline MCoTI-based cyclotides & CXCR4 & $\begin{array}{l}\mathrm{IC}_{50}=20 \mathrm{nM} \\
\left.\mathrm{EC}_{50} \text { (HIV entry }\right)=2 \mathrm{nM}\end{array}$ & 179 \\
\hline $\begin{array}{l}\text { Peptides T22 and T140 } \\
\text { Polyphemusin II-related synthetic 14-16-meric } \\
\text { derivatives }\end{array}$ & CXCR4 & $\mathrm{IC}_{50}=17 \mathrm{nM}$ & 153,154 \\
\hline $\begin{array}{l}\text { Cyclopentapeptide FC131 } \\
\text { Head-to-tail-cyclized variant of T140 }\end{array}$ & CXCR4 & $\mathrm{I} C_{50}=8 \mathrm{nM}$ & 154 \\
\hline $\begin{array}{l}\text { Peptoid } 8 \\
\text { Peptoid derivative of FC131 }\end{array}$ & CXCR4 & $\begin{array}{l}\mathrm{IC}_{50}=40 \mathrm{pM} \\
\mathrm{EC}_{50} \text { (HIV entry) }=29 \mathrm{nM}\end{array}$ & 156 \\
\hline
\end{tabular}

Abbreviations: CDR, complementarity-determining region; HIV, human immunodeficiency virus; MIF, migration inhibitory factor; MOG, myelin oligodendrocyte glycoprotein.

Note: IC50 refers to replacement of ligand (MIF, CXCL12) from receptor (CD74, CXCR4).

interaction have been developed based on antigenic peptideloaded fragments of class II resulting in reduced severity of experimental autoimmune encephalomyelitis, the experimental mouse model of multiple sclerosis. ${ }^{104,105,107}$ One such peptide is the DR2-restricted myelin determinant mouse (m) myelin oligodendrocyte glycoprotein (MOG)-35-55 covalently linked to a human leukocyte antigen-DR 1 domain (the 'DR 1-MOG-35-55' construct) and has been found to reduce central nervous system inflammation and tissue injury in models of multiple sclerosis, ischaemic stroke and traumatic brain injury. ${ }^{104,105,107,147}$ RTL1000 is a variant of this construct additionally containing the $\beta 1$ domain of DR1 ('DR $\alpha 1 \beta 1-M O G$ 35-55') and is in clinical studies for multiple sclerosis. ${ }^{148,149}$ It is thought that these peptide constructs interfere with MIF/ CD74-driven neuroinflammation. ${ }^{150}$

A note of caution should be sounded regarding their potential application in atherosclerosis and cardiovascular disease settings due to the protective role of the MIF/CD74 axis in ischaemic heart disease. ${ }^{19,58}$

As discussed above, SARs have identified the motifs and residues contributing to the interface between MIF and CXCR2/4 and highlighted differences compared with the classical chemokine ligands CXCL8/1 and CXCL12, respectively. The two-site binding mechanism for MIF and CXCR2 is similar but not identical to that for CXCL1/8, while significant differences were noted for the binding interface of MIF/ CXCR4 versus CXCL12/CXCR4. 14,16,74-76,81,82 Peptides served as important tools in these studies and some of them might become templates for peptide-based anti-MIF strategies in atherosclerosis and inflammation. For example, MIF peptide 47-56, spanning the $\mathrm{N}$-like loop that contributes to site 1 binding with CXCR2, competes with MIF binding to CXCR2 and MIF-mediated atherogenic leukocyte arrest. ${ }^{16,76}$ Stabilized variants of this peptide or related ones spanning MIF 


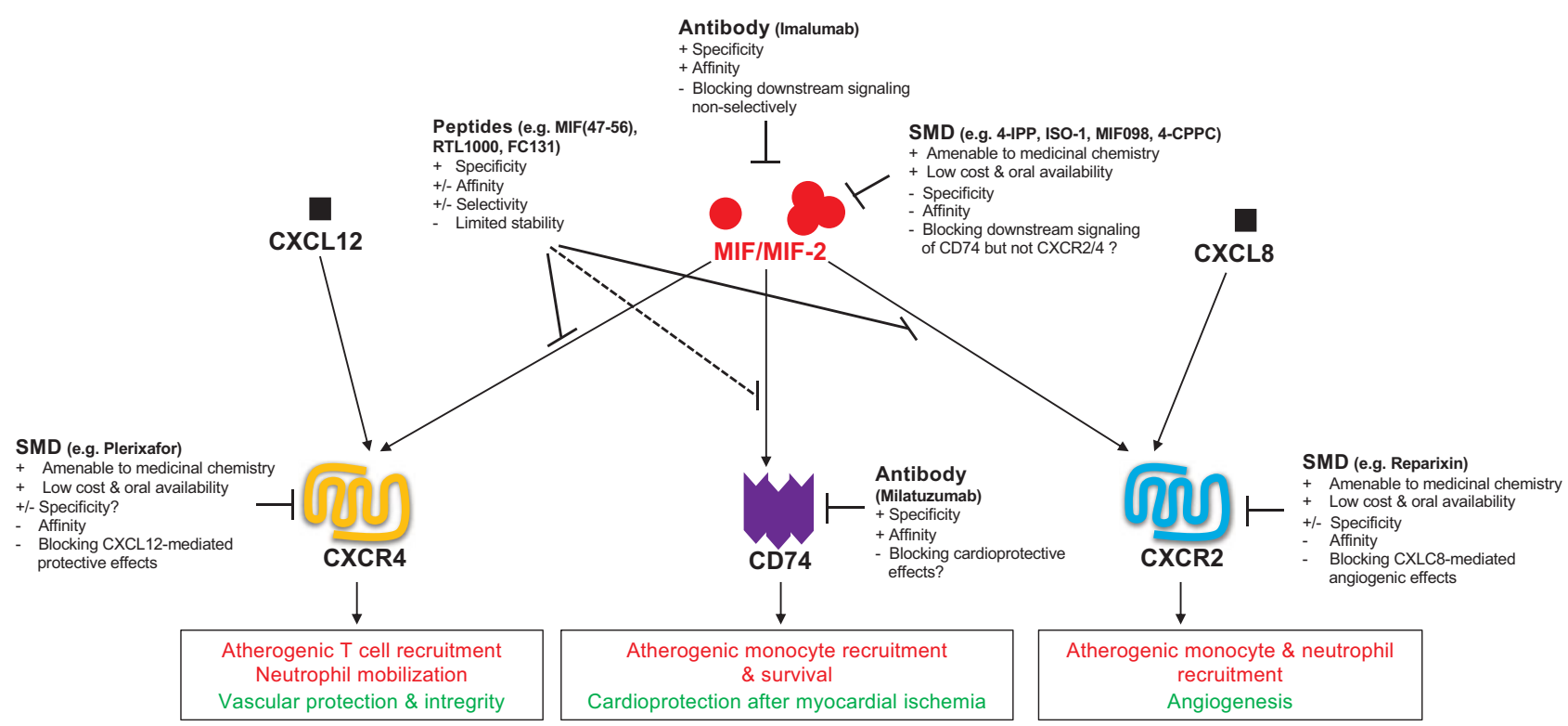

Fig. 1 Overview of inhibitory approaches to target the macrophage migration inhibitory factor (MIF)/receptor network in atherosclerosis. The potential utility of all three classes of anti-MIF network inhibitors, that is, antibodies, small molecule drug (SMD) compounds and peptides, in attenuating atherosclerosis and/or atherogenic inflammation is indicated with respect to MIF and MIF-2/D-dopachrome tautomerase (D-DT), as well as the MIF receptors CXCR4, CD74 and CXCR2. The pros and cons for each inhibitor-type regarding each target ligand/receptor or pathway are indicated by scoring their properties (e.g. specificity) with,++ /- or -. The outcome boxes are colour-coded (red, pro-atherogenic; green, athero-/cardioprotective).

regions contributing to site 1 or 2 binding might qualify as interesting templates for the future development of MIFbased peptide drugs against atherogenic inflammation.

MIF acts as a partial allosteric agonist of CXCL12, consistent with the notion that the binding interface between MIF and CXCR4 differs from that of CXCL12 and CXCR4. ${ }^{82}$ Major differences are the contributions of the extended N-like loop and the cavity around Pro- 2 in MIF ${ }^{81,82}$ and the RFFESH motif in CXCL12. ${ }^{80,151}$ This SAR information as well as the crystal structures of MIF and of CXCR4 in complex with small molecules and cyclic peptides give valuable hints as to the development of peptide inhibitors that may specifically block MIF-driven responses. ${ }^{80}$

Of note, CXCR4 pathways have already been targeted by peptide inhibitor strategies. CVX15, a 16-residue cyclic peptide analogue of the horseshoe crab peptide polyphemusin, was co-crystallized with CXCR $4^{80}$ and characterized as an HIV-inhibiting and anti-metastatic agent. ${ }^{152,153}$ Polyphemusin II-related synthetic peptides T22, T140 and FC131 were pioneered by Fujii et al to adopt a $\beta$-hairpin conformation stabilized by disulphide bonds, resulting in high-affinity CXCR4 inhibitory peptides with a low nanomolar $\mathrm{IC}_{50} .^{153-155}$ This principle was developed further by Kessler and colleagues, who furthered the principle of protein-epitope mimetics and devised novel classes of super high-affinity CXCR4-targeting cyclopeptides, ${ }^{156,157}$ for example, by 'freezing' the conformation of a CXCR4 ligand into a single-active conformation by using a 'peptoid' motif. ${ }^{156}$ In another approach, peptide inhibitors were derived from the N-terminal of CXCL12 and further optimized and stabilized to give rise to sub-nanomolar serum-stable CXCL12/CXCR4 inhibitors with anti-metastatic activity in vitro. ${ }^{158,159}$ Furthermore, peptides based on the sequence of CXCR4 were linked in an attempt to mimic the ecto-surface of CXCR4 and shown to compete with HIV-gp120 and HIV entry. ${ }^{160,161}$ MIF is not able to inhibit HIV entry ${ }^{82}$ and peptides targeting the MIF/CXCR4 axis have not been systematically studied, although a peptide spanning the RLR motif of MIF competes with MIF-mediated lymphocyte migration. ${ }^{81}$

\section{Conclusion}

MIF is a pivotal mediator of atherosclerosis, MIF-2/D-DT shares critical inflammatory activities with MIF and the MIF receptors CD74, CXCR2 and CXCR4 have all been implicated in atherosclerosis, suggesting that it will be important to develop therapeutic strategies against MIF proteins in atherosclerosis. Importantly, the MIF network is amenable to targeting by all major inhibitor classes, that is, small molecule compounds, antibodies and peptides (-Fig. 1). In fact, inhibitors against MIF and/or its receptors from all three classes are in clinical development and the CXCR4 blocker AMD3100, which is a partial inhibitor of MIF/CXCR4 binding, is an FDA-approved drug in cancer. However, to make such strategies applicable for cardiovascular disease, MIF pathway-specific concepts need to be developed that specifically target the atheroprogressive activities of MIF.

Considering the Janus-faced effects of MIF proteins in cardiovascular complications and the complex homeostatic and inflammatory roles of their receptors, this is a challenging task. One strategy might be to specifically target the MIF/CXCR2 interface which is atheropromoting and largely detrimental in the myocardium during an ischaemic insult. Both antibodies and peptide-based compounds such as stabilized derivatives of MIF $^{47-56}$ could potentially qualify as MIF/CXCR2-specific agents. Similarly, inhibitor strategies 
specifically targeting the MIF/CXCR4 interaction could be envisioned, although great caution would need to be taken to spare the various protective activities of CXCR4 in the atherogenic vasculature and the ischaemic-stressed heart. On the other hand, the cardioprotective effect of MIF and MIF-2 observed in the early phase following MI/RI provides a narrow albeit critical therapeutic window to pharmacologically promote the cardioprotective function of MIF before late-phase inflammatory responses kick in. This could especially be relevant in cardiac surgery patients and one relevant agent is the small molecule agonist MIF-20, which binds near MIF's tautomerase pocket and has been reported to have protective effects in an experimental model of cardiac ischaemic injury. ${ }^{162}$ Such a 'pharmacological augmentation' strategy would be selective to MIF proteins due to their structurally unique tautomerase cavity and might become particularly important in cohorts of patients identified as MIF 'low expressers.' ${ }^{19,58}$ Therapeutically, a combinatorial treatment approach might be considered, in which the cardioprotective effect of MIF in the early phase of MI/RI is carefully and phase-specifically enhanced, followed by phase-specific pharmacological inhibition in the lateinflammatory-phase of MI/RI. Whether any anti-MIF strategy would qualify as a treatment regimen to 'prevent' or 'reverse' chronic atherogenesis similar to canakinumab will have to be subject to comprehensive future investigations. Reversal of atherosclerotic lesions as observed in an experimental mouse model of plaque regression applying anti-MIF but not anti-CXCL12 or anti-CXCL1 antibodies is a promising start in this direction. ${ }^{14}$

In conclusion, for applications in atherosclerotic cardiovascular disease, MIF pathway-specific concepts would need to (1) specifically target the atheroprogressive activities of MIF, (2) preserve homeostatic effects of intracellular MIF, (3) take into account the cardioprotective functions of CD74, and/or (4) spare CXCL12/CXCR4-dependent vascular protection pathways. Molecular characteristics of such agents would need to account for the necessities of chronic treatment over the course of lesion development and/or phasespecificity in the sequelae related to acute cardiac ischaemia.

\section{Funding}

This work was supported by Deutsche Forschungsgemeinschaft (DFG) grant SFB1123-A03 to J.B. and A.K., SFB1123-B03 to Y.A., by DFG within the framework of Munich Cluster for Systems Neurology (EXC 1010 SyNergy) and of LMUexc (LMU-Singapore strategic partnership) to J.B.

\section{Conflict of Interest}

J.B. is a co-inventor of patents covering anti-MIF strategies in inflammatory and cardiovascular diseases. Other authors declare no additional conflict of interest.

\section{References}

1 Ross R. Atherosclerosis-an inflammatory disease. N Engl J Med 1999;340(02):115-126
2 Libby P, Ridker PM, Maseri A. Inflammation and atherosclerosis. Circulation 2002;105(09):1135-1143

3 Dahlöf B. Cardiovascular disease risk factors: epidemiology and risk assessment. Am J Cardiol 2010;105(1, Suppl): $3 \mathrm{~A}-9 \mathrm{~A}$

4 van der Vorst EP, Döring Y, Weber C. Chemokines and their receptors in atherosclerosis. J Mol Med (Berl) 2015;93(09): 963-971

5 Charo IF, Ransohoff RM. The many roles of chemokines and chemokine receptors in inflammation. N Engl J Med 2006;354 (06):610-621

6 Bachelerie F, Ben-Baruch A, Burkhardt AM, et al. International Union of Basic and Clinical Pharmacology. [corrected]. LXXXIX. Update on the extended family of chemokine receptors and introducing a new nomenclature for atypical chemokine receptors. Pharmacol Rev 2013;66(01):1-79

7 Weber C, Noels H. Atherosclerosis: current pathogenesis and therapeutic options. Nat Med 2011;17(11):1410-1422

8 Bäck M, Hansson GK. Anti-inflammatory therapies for atherosclerosis. Nat Rev Cardiol 2015;12(04):199-211

9 Ridker PM, Lüscher TF. Anti-inflammatory therapies for cardiovascular disease. Eur Heart J 2014;35(27):1782-1791

10 Ramji DP, Davies TS. Cytokines in atherosclerosis: key players in all stages of disease and promising therapeutic targets. Cytokine Growth Factor Rev 2015;26(06):673-685

11 Ruparelia N, Chai JT, Fisher EA, Choudhury RP. Inflammatory processes in cardiovascular disease: a route to targeted therapies. Nat Rev Cardiol 2017;14(03):133-144

12 Ridker PM, Everett BM, Thuren T, et al; CANTOS Trial Group. Antiinflammatory therapy with canakinumab for atherosclerotic disease. N Engl J Med 2017;377(12):1119-1131

13 Bernhagen J, Calandra T, Mitchell RA, et al. MIF is a pituitaryderived cytokine that potentiates lethal endotoxaemia. Nature 1993;365(6448):756-759

14 Bernhagen J, Krohn R, Lue H, et al. MIF is a noncognate ligand of CXC chemokine receptors in inflammatory and atherogenic cell recruitment. Nat Med 2007;13(05):587-596

15 Calandra T, Roger T. Macrophage migration inhibitory factor: a regulator of innate immunity. Nat Rev Immunol 2003;3(10): 791-800

16 Tillmann S, Bernhagen J, Noels H. Arrest functions of the MIF ligand/receptor axes in atherogenesis. Front Immunol 2013;4:115

17 Burger-Kentischer A, Goebel H, Seiler R, et al. Expression of MIF in different stages of human atherosclerosis. Circulation 2002; 105(13):1561-1566

18 Zernecke A, Bernhagen J, Weber C. Macrophage migration inhibitory factor in cardiovascular disease. Circulation 2008;117 (12):1594-1602

19 Tilstam PV, Qi D, Leng L, Young L, Bucala R. MIF family cytokines in cardiovascular diseases and prospects for precisionbased therapeutics. Expert Opin Ther Targets 2017;21(07): 671-683

20 David JR. Delayed hypersensitivity in vitro: its mediation by cellfree substances formed by lymphoid cell-antigen interaction. Proc Natl Acad Sci U S A 1966;56(01):72-77

21 Rich AR, Lewis MR. Migration of neutrophils and macrophages. Bull Johns Hopkins Hosp 1932;50:115-131

22 Mischke R, Kleemann R, Brunner H, Bernhagen J. Cross-linking and mutational analysis of the oligomerization state of the cytokine macrophage migration inhibitory factor (MIF). FEBS Lett 1998;427(01):85-90

23 Sun HW, Bernhagen J, Bucala R, Lolis E. Crystal structure at 2.6-A resolution of human macrophage migration inhibitory factor. Proc Natl Acad Sci U S A 1996;93(11):5191-5196

24 Lolis E, Bucala R. Macrophage migration inhibitory factor. Expert Opin Ther Targets 2003;7(02):153-164

25 Flieger O, Engling A, Bucala R, Lue H, Nickel W, Bernhagen J. Regulated secretion of macrophage migration inhibitory factor is 
mediated by a non-classical pathway involving an $A B C$ transporter. FEBS Lett 2003;551(1-3):78-86

26 Merk M, Baugh J, Zierow S, et al. The Golgi-associated protein p115 mediates the secretion of macrophage migration inhibitory factor. J Immunol 2009;182(11):6896-6906

27 Hertelendy J, Reumuth G, Simons D, et al. Macrophage migration inhibitory factor - a favorable marker in inflammatory diseases? Curr Med Chem 2018;25(05):601-605

28 Morand EF, Leech M, Bernhagen J. MIF: a new cytokine link between rheumatoid arthritis and atherosclerosis. Nat Rev Drug Discov 2006;5(05):399-410

29 Morrison MC, Kleemann R. Role of macrophage migration inhibitory factor in obesity, insulin resistance, type 2 diabetes, and associated hepatic co-morbidities: a comprehensive review of human and rodent studies. Front Immunol 2015;6:308

30 Sauler M, Bucala R, Lee PJ. Role of macrophage migration inhibitory factor in age-related lung disease. Am J Physiol Lung Cell Mol Physiol 2015;309(01):L1-L10

31 O'Reilly C, Doroudian M, Mawhinney L, Donnelly SC. Targeting MIF in cancer: therapeutic strategies, current developments, and future opportunities. Med Res Rev 2016;36(03):440-460

32 Conroy H, Mawhinney L, Donnelly SC. Inflammation and cancer: macrophage migration inhibitory factor (MIF)-the potential missing link. OJM 2010;103(11):831-836

33 Chesney JA, Mitchell RA, Yaddanapudi K. Myeloid-derived suppressor cells-a new therapeutic target to overcome resistance to cancer immunotherapy. J Leukoc Biol 2017;102(03):727-740

34 Chesney JA, Mitchell RA. 25 years on: a retrospective on migration inhibitory factor in tumor angiogenesis. Mol Med 2015;21 (Suppl 1):S19-S24

35 Wirtz TH, Tillmann S, Strüßmann T, et al. Platelet-derived MIF: a novel platelet chemokine with distinct recruitment properties. Atherosclerosis 2015;239(01):1-10

36 Lin SG, Yu XY, Chen YX, et al. De novo expression of macrophage migration inhibitory factor in atherogenesis in rabbits. Circ Res 2000;87(12):1202-1208

37 Burger-Kentischer A, Göbel H, Kleemann R, et al. Reduction of the aortic inflammatory response in spontaneous atherosclerosis by blockade of macrophage migration inhibitory factor (MIF). Atherosclerosis 2006;184(01):28-38

38 Pan JH, Sukhova GK, Yang JT, et al. Macrophage migration inhibitory factor deficiency impairs atherosclerosis in low-density lipoprotein receptor-deficient mice. Circulation 2004;109 (25):3149-3153

39 Amin MA, Haas CS, Zhu K, et al. Migration inhibitory factor upregulates vascular cell adhesion molecule-1 and intercellular adhesion molecule-1 via Src, PI3 kinase, and NFkappaB. Blood 2006;107(06):2252-2261

40 Gregory JL, Morand EF, McKeown SJ, et al. Macrophage migration inhibitory factor induces macrophage recruitment via CC chemokine ligand 2. J Immunol 2006;177(11):8072-8079

41 Atsumi T, Nishihira J, Makita Z, Koike T. Enhancement of oxidised low-density lipoprotein uptake by macrophages in response to macrophage migration inhibitory factor. Cytokine 2000;12(10): 1553-1556

42 Kong YZ, Huang XR, Ouyang X, et al. Evidence for vascular macrophage migration inhibitory factor in destabilization of human atherosclerotic plaques. Cardiovasc Res 2005;65(01): 272-282

43 Calandra T, Bernhagen J, Metz CN, et al. MIF as a glucocorticoidinduced modulator of cytokine production. Nature 1995;377 (6544):68-71

44 Luo JY, Xu R, Li XM, et al. MIF gene polymorphism rs755622 is associated with coronary artery disease and severity of coronary lesions in a Chinese Kazakh population: a case-control study. Medicine (Baltimore) 2016;95(04):e2617

45 Herder C, Illig T, Baumert J, et al. Macrophage migration inhibitory factor (MIF) and risk for coronary heart disease: results from the MONICA/KORA Augsburg case-cohort study, 1984-2002. Atherosclerosis 2008;200(02):380-388

$46 \mathrm{Ji} \mathrm{K}$, Wang X, Li J, et al. Macrophage migration inhibitory factor polymorphism is associated with susceptibility to inflammatory coronary heart disease. BioMed Res Int 2015;2015:315174

47 Baugh JA, Chitnis S, Donnelly SC, et al. A functional promoter polymorphism in the macrophage migration inhibitory factor (MIF) gene associated with disease severity in rheumatoid arthritis. Genes Immun 2002;3(03):170-176

48 Lan MY, Chang YY, Chen WH, et al. Association between MIF gene polymorphisms and carotid artery atherosclerosis. Biochem Biophys Res Commun 2013;435(02):319-322

49 Müller II, Müller KA, Karathanos A, et al. Impact of counterbalance between macrophage migration inhibitory factor and its inhibitor Gremlin-1 in patients with coronary artery disease. Atherosclerosis 2014;237(02):426-432

50 Müller II, Müller KAL, Schönleber H, et al. Macrophage migration inhibitory factor is enhanced in acute coronary syndromes and is associated with the inflammatory response. PLoS One 2012;7 (06):e38376

51 Deng XN, Wang XY, Yu HY, et al. Admission macrophage migration inhibitory factor predicts long-term prognosis in patients with ST-elevation myocardial infarction. Eur Heart J Qual Care Clin Outcomes 2018;4(03):208-219

52 Deng F, Zhao Q, Deng Y, et al. Prognostic significance and dynamic change of plasma macrophage migration inhibitory factor in patients with acute ST-elevation myocardial infarction. Medicine (Baltimore) 2018;97(43):e12991

53 Chan W, White DA, Wang XY, et al. Macrophage migration inhibitory factor for the early prediction of infarct size. J Am Heart Assoc 2013;2(05):e000226

54 Stoppe C, Rex S, Goetzenich A, et al. Interaction of MIF family proteins in myocardial ischemia/reperfusion damage and their influence on clinical outcome of cardiac surgery patients. Antioxid Redox Signal 2015;23(11):865-879

55 Stoppe C, Werker T, Rossaint R, et al. What is the significance of perioperative release of macrophage migration inhibitory factor in cardiac surgery? Antioxid Redox Signal 2013;19(03):231-239

56 Stoppe C, Averdunk L, Goetzenich A, et al. The protective role of macrophage migration inhibitory factor in acute kidney injury after cardiac surgery. Sci Transl Med 2018;10(441):eaan4886

57 Luedike P, Hendgen-Cotta UB, Sobierajski J, et al. Cardioprotection through S-nitros(yl)ation of macrophage migration inhibitory factor. Circulation 2012;125(15):1880-1889

58 Miller EJ, Li J, Leng L, et al. Macrophage migration inhibitory factor stimulates AMP-activated protein kinase in the ischaemic heart. Nature 2008;451(7178):578-582

59 Pohl J, Hendgen-Cotta UB, Rammos C, et al. Targeted intracellular accumulation of macrophage migration inhibitory factor in the reperfused heart mediates cardioprotection. Thromb Haemost 2016;115(01):200-212

60 Qi D, Hu X, Wu X, et al. Cardiac macrophage migration inhibitory factor inhibits JNK pathway activation and injury during ischemia/reperfusion. J Clin Invest 2009;119(12):3807-3816

61 Rassaf T, Weber C, Bernhagen J. Macrophage migration inhibitory factor in myocardial ischaemia/reperfusion injury. Cardiovasc Res 2014;102(02):321-328

62 Koga K, Kenessey A, Powell SR, Sison CP, Miller EJ, Ojamaa K. Macrophage migration inhibitory factor provides cardioprotection during ischemia/reperfusion by reducing oxidative stress. Antioxid Redox Signal 2011;14(07):1191-1202

63 Qi D, Atsina K, Qu L, et al. The vestigial enzyme D-dopachrome tautomerase protects the heart against ischemic injury. J Clin Invest 2014;124(08):3540-3550

64 Dayawansa NH, Gao X-M, White DA, Dart AM, Du XJ. Role of MIF in myocardial ischaemia and infarction: insight from recent clinical and experimental findings. Clin Sci (Lond) 2014;127 (03):149-161 
65 Leng L, Metz CN, Fang Y, et al. MIF signal transduction initiated by binding to CD74. J Exp Med 2003;197(11):1467-1476

$66 \mathrm{Ma} \mathrm{H}$, Wang J, Thomas DP, et al. Impaired macrophage migration inhibitory factor-AMP-activated protein kinase activation and ischemic recovery in the senescent heart. Circulation 2010;122 (03):282-292

67 Schindler L, Dickerhof N, Hampton MB, et al. Post-translational regulation of MIF: basis for functional fine-tuning. Redox Biol 2018;15:135-142

68 Liehn EA, Kanzler I, Konschalla S, et al. Compartmentalized protective and detrimental effects of endogenous MIF mediated by CXCR2 in a mouse model of myocardial ischemia/reperfusion. Arterioscler Thromb Vasc Biol 2013;33(09):2180-2186

69 Liehn EA, Tuchscheerer N, Kanzler I, et al. Double-edged role of the CXCL12/CXCR4 axis in experimental myocardial infarction. J Am Coll Cardiol 2011;58(23):2415-2423

70 Alampour-Rajabi S, El Bounkari O, Rot A, et al. MIF interacts with CXCR7 to promote receptor internalization, ERK1/2 and ZAP-70 signaling, and lymphocyte chemotaxis. FASEB J 2015;29(11): 4497-4511

71 Chatterjee M, Borst O, Walker B, et al. Macrophage migration inhibitory factor limits activation-induced apoptosis of platelets via CXCR7-dependent Akt signaling. Circ Res 2014;115(11): 939-949

72 Tarnowski M, Grymula K, Liu R, et al. Macrophage migration inhibitory factor is secreted by rhabdomyosarcoma cells, modulates tumor metastasis by binding to CXCR4 and CXCR7 receptors and inhibits recruitment of cancer-associated fibroblasts. Mol Cancer Res 2010;8(10):1328-1343

73 Cho Y, Crichlow GV, Vermeire JJ, et al. Allosteric inhibition of MIF revealed by ibudilast. Proc Natl Acad Sci U S A 2010;107(25): 11313-11318

$74 \mathrm{Xu} \mathrm{L,} \mathrm{Li} \mathrm{Y,} \mathrm{Li} \mathrm{D,} \mathrm{et} \mathrm{al.} \mathrm{Exploring} \mathrm{the} \mathrm{binding} \mathrm{mechanisms} \mathrm{of} \mathrm{MIF} \mathrm{to}$ CXCR2 using theoretical approaches. Phys Chem Chem Phys 2015;17(05):3370-3382

75 Weber C, Kraemer S, Drechsler M, et al. Structural determinants of MIF functions in CXCR2-mediated inflammatory and atherogenic leukocyte recruitment. Proc Natl Acad Sci U S A 2008;105 (42):16278-16283

76 Kraemer S, Lue H, Zernecke A, et al. MIF-chemokine receptor interactions in atherogenesis are dependent on an N-loop-based 2-site binding mechanism. FASEB J 2011;25(03):894-906

77 Klasen C, Ohl K, Sternkopf M, et al. MIF promotes B cell chemotaxis through the receptors CXCR4 and CD74 and ZAP-70 signaling. J Immunol 2014;192(11):5273-5284

78 Schmitz C, Noels H, El Bounkari O, et al. Mif-deficiency favors an atheroprotective autoantibody phenotype in atherosclerosis. FASEB J 2018;32(08):4428-4443

79 Qin L, Kufareva I, Holden LG, et al. Structural biology. Crystal structure of the chemokine receptor CXCR4 in complex with a viral chemokine. Science 2015;347(6226):1117-1122

80 Wu B, Chien EY, Mol CD, et al. Structures of the CXCR4 chemokine GPCR with small-molecule and cyclic peptide antagonists. Science 2010;330(6007):1066-1071

81 Lacy M, Kontos C, Brandhofer M, et al. Identification of an ArgLeu-Arg tripeptide that contributes to the binding interface between the cytokine MIF and the chemokine receptor CXCR4. Sci Rep 2018;8(01):5171

82 Rajasekaran D, Gröning S, Schmitz C, et al. Macrophage migration inhibitory factor-CXCR4 receptor interactions: evidence for partial allosteric agonism in comparison with CXCL12 chemokine. J Biol Chem 2016;291(30):15881-15895

83 Schwartz V, Lue H, Kraemer S, et al. A functional heteromeric MIF receptor formed by CD74 and CXCR4. FEBS Lett 2009;583(17): 2749-2757

84 Klasen C, Ziehm T, Huber M, et al. LPS-mediated cell surface expression of CD74 promotes the proliferation of B cells in response to MIF. Cell Signal 2018;46:32-42
85 Bertolino P, Rabourdin-Combe C. The MHC class II-associated invariant chain: a molecule with multiple roles in MHC class II biosynthesis and antigen presentation to CD4+ T cells. Crit Rev Immunol 1996;16(04):359-379

86 Merk M, Zierow S, Leng L, et al. The D-dopachrome tautomerase (DDT) gene product is a cytokine and functional homolog of macrophage migration inhibitory factor (MIF). Proc Natl Acad Sci U S A 2011;108(34):E577-E585

87 Shi X, Leng L, Wang T, et al. CD44 is the signaling component of the macrophage migration inhibitory factor-CD74 receptor complex. Immunity 2006;25(04):595-606

88 Assis DN, Leng L, Du X, et al. The role of macrophage migration inhibitory factor in autoimmune liver disease. Hepatology 2014; 59(02):580-591

89 Monaco C, Nanchahal J, Taylor P, Feldmann M. Anti-TNF therapy: past, present and future. Int Immunol 2015;27(01):55-62

90 Loberg RD, Ying C, Craig M, Yan L, Snyder LA, Pienta KJ. CCL2 as an important mediator of prostate cancer growth in vivo through the regulation of macrophage infiltration. Neoplasia 2007;9(07): 556-562

91 Loberg RD, Ying C, Craig M, et al. Targeting CCL2 with systemic delivery of neutralizing antibodies induces prostate cancer tumor regression in vivo. Cancer Res 2007;67(19):9417-9424

92 Calandra T, Echtenacher B, Roy DL, et al. Protection from septic shock by neutralization of macrophage migration inhibitory factor. Nat Med 2000;6(02):164-170

93 Kerschbaumer RJ, Rieger M, Völkel D, et al. Neutralization of macrophage migration inhibitory factor (MIF) by fully human antibodies correlates with their specificity for the $\beta$-sheet structure of MIF. J Biol Chem 2012;287(10):7446-7455

94 Lan HY, Bacher M, Yang N, et al. The pathogenic role of macrophage migration inhibitory factor in immunologically induced kidney disease in the rat. J Exp Med 1997;185(08):1455-1465

95 Bloom J, Sun S, Al-Abed Y. MIF, a controversial cytokine: a review of structural features, challenges, and opportunities for drug development. Expert Opin Ther Targets 2016;20(12):1463-1475

96 Zhang Y, Zeng X, Chen S, et al. Characterization, epitope identification and mechanisms of the anti-septic capacity of monoclonal antibodies against macrophage migration inhibitory factor. Int Immunopharmacol 2011;11(09):1333-1340

97 Mahalingam D, Patel M, Sachdev J, et al. Safety and efficacy analysis of imalumab, an anti-oxidized macrophage migration inhibitory factor (oxMIF) antibody, alone or in combination with 5-fluorouracil/leucovorin (5-FU/LV) or panitumumab, in patients with metastatic colorectal cancer (mCRC). Ann Oncol 2016;2016:ii105

98 Thiele M, Kerschbaumer RJ, Tam FW, et al. Selective targeting of a disease-related conformational isoform of MIF ameliorates inflammatory conditions. J Immunol 2015;195(05):2343-2352

99 Schinagl A, Kerschbaumer RJ, Sabarth N, et al. Role of the cysteine 81 residue of MIF as a molecular redox switch. Biochemistry 2018;57(09):1523-1532

100 Schinagl A, Thiele M, Douillard P, et al. Oxidized MIF is a potential new tissue marker and drug target in cancer. Oncotarget 2016;7 (45):73486-73496

101 Ochi A, Chen D, Schulte W, et al. MIF-2/D-DT enhances proximal tubular cell regeneration through SLPI- and ATF4-dependent mechanisms. Am J Physiol Renal Physiol 2017;313(03): F767-F780

102 Pohl J, Hendgen-Cotta UB, Stock P, Luedike P, Rassaf T. Elevated MIF-2 levels predict mortality in critically ill patients. J Crit Care 2017;40:52-57

103 Merk M, Mitchell RA, Endres S, Bucala R. D-dopachrome tautomerase (D-DT or MIF-2): doubling the MIF cytokine family. Cytokine 2012;59(01):10-17

104 Benedek G, Meza-Romero R, Jordan K, Keenlyside L, Offner H, Vandenbark AA. HLA-DR $\alpha 1-$ MMOG-35-55 treatment of experimental autoimmune encephalomyelitis reduces CNS 
inflammation, enhances M2 macrophage frequency, and promotes neuroprotection. J Neuroinflammation 2015;12:123

105 Meza-Romero R, Benedek G, Yu X, et al. HLA-DR $\alpha 1$ constructs block CD74 expression and MIF effects in experimental autoimmune encephalomyelitis. J Immunol 2014;192(09): 4164-4173

106 Vandenbark AA, Meza-Romero R, Benedek G, et al. A novel regulatory pathway for autoimmune disease: binding of partial MHC class II constructs to monocytes reduces CD74 expression and induces both specific and bystander T-cell tolerance. J Autoimmun 2013;40:96-110

107 Benedek G, Meza-Romero R, Andrew S, et al. Partial MHC class II constructs inhibit MIF/CD74 binding and downstream effects. Eur J Immunol 2013;43(05):1309-1321

108 Berkova Z, Tao RH, Samaniego F. Milatuzumab - a promising new immunotherapeutic agent. Expert Opin Investig Drugs 2010;19 (01):141-149

109 Borghese F, Clanchy FI. CD74: an emerging opportunity as a therapeutic target in cancer and autoimmune disease. Expert Opin Ther Targets 2011;15(03):237-251

110 Sun J, Hartvigsen K, Chou MY, et al. Deficiency of antigenpresenting cell invariant chain reduces atherosclerosis in mice. Circulation 2010;122(08):808-820

111 Dolgin E. First GPCR-directed antibody passes approval milestone. Nat Rev Drug Discov 2018;17(07):457-459

112 Peng L, Damschroder MM, Cook KE, Wu H, Dall'Acqua WF. Molecular basis for the antagonistic activity of an anti-CXCR4 antibody. MAbs 2016;8(01):163-175

113 Jantunen E. Novel strategies for blood stem cell mobilization: special focus on plerixafor. Expert Opin Biol Ther 2011;11(09): 1241-1248

114 Zernecke A, Bot I, Djalali-Talab Y, et al. Protective role of CXC receptor 4/CXC ligand 12 unveils the importance of neutrophils in atherosclerosis. Circ Res 2008;102(02):209-217

115 Döring Y, Noels H, van der Vorst EPC, et al. Vascular CXCR4 limits atherosclerosis by maintaining arterial integrity: evidence from mouse and human studies. Circulation 2017;136(04):388-403

116 Boisvert WA, Santiago R, Curtiss LK, Terkeltaub RA. A leukocyte homologue of the IL-8 receptor CXCR-2 mediates the accumulation of macrophages in atherosclerotic lesions of LDL receptordeficient mice. J Clin Invest 1998;101(02):353-363

117 Boisvert WA, Curtiss LK, Terkeltaub RA. Interleukin- 8 and its receptor CXCR2 in atherosclerosis. Immunol Res 2000;21(23):129-137

118 Highfill SL, Cui Y, Giles AJ, et al. Disruption of CXCR2-mediated MDSC tumor trafficking enhances anti-PD1 efficacy. Sci Transl Med 2014;6(237):237ra67

119 Stadtmann A, Zarbock A. CXCR2: from bench to bedside. Front Immunol 2012;3:263

120 Joseph JP, Reyes E, Guzman J, et al. CXCR2 inhibition - a novel approach to treating CoronAry heart DiseAse (CICADA): study protocol for a randomised controlled trial. Trials 2017;18(01): 473

121 Kok T, Wasiel AA, Cool RH, et al. Small-molecule inhibitors of MIF as an emerging class of therapeutics for immune disorders. Drug Discov Today 2018;23(11):1910-1918

122 Trivedi-Parmar V, Jorgensen WL. Advances and insights for small molecule inhibition of macrophage migration inhibitory factor. J Med Chem 2018;61(18):8104-8119

123 Ouertatani-Sakouhi H, El-Turk F, Fauvet B, et al. Identification and characterization of novel classes of macrophage migration inhibitory factor (MIF) inhibitors with distinct mechanisms of action. J Biol Chem 2010;285(34):26581-26598

124 Bai F, Asojo OA, Cirillo P, et al. A novel allosteric inhibitor of macrophage migration inhibitory factor (MIF).J Biol Chem 2012; 287(36):30653-30663

125 Pantouris G, Bucala R, Lolis EJ. Structural plasticity in the Cterminal region of macrophage migration inhibitory factor- 2 is associated with an induced fit mechanism for a selective inhibitor. Biochemistry 2018;57(26):3599-3605

126 Fingerle-Rowson G, Kaleswarapu DR, Schlander C, et al. A tautomerase-null macrophage migration-inhibitory factor (MIF) gene knock-in mouse model reveals that protein interactions and not enzymatic activity mediate MIF-dependent growth regulation. Mol Cell Biol 2009;29(07):1922-1932

127 Pantouris G, Syed MA, Fan C, et al. An analysis of MIF structural features that control functional activation of CD74. Chem Biol 2015;22(09):1197-1205

128 Cournia Z, Leng L, Gandavadi S, et al. Discovery of human MIFCD74 antagonists via virtual screening. J Med Chem 2009;52 (02):416-424

129 Jorgensen WL, Gandavadi S, Du X, et al. Receptor agonists of macrophage migration inhibitory factor. Bioorg Med Chem Lett 2010;20(23):7033-7036

130 Lubetsky JB, Dios A, Han J, et al. The tautomerase active site of macrophage migration inhibitory factor is a potential target for discovery of novel anti-inflammatory agents. J Biol Chem 2002; 277(28):24976-24982

131 Senter PD, Al-Abed Y, Metz CN, et al. Inhibition of macrophage migration inhibitory factor (MIF) tautomerase and biological activities by acetaminophen metabolites. Proc Natl Acad Sci U S A 2002;99(01):144-149

132 Fox RJ, Coffey CS, Conwit R, et al; NN102/SPRINT-MS Trial Investigators. Phase 2 trial of Ibudilast in progressive multiple sclerosis. N Engl J Med 2018;379(09):846-855

133 Brown KK, Blaikie FH, Smith RA, et al. Direct modification of the proinflammatory cytokine macrophage migration inhibitory factor by dietary isothiocyanates. J Biol Chem 2009;284(47): 32425-32433

134 Priego N, Zhu L, Monteiro C, et al. STAT3 labels a subpopulation of reactive astrocytes required for brain metastasis. Nat Med 2018; 24(07):1024-1035

135 Heinrichs D, Berres M-L, Coeuru M, et al. Protective role of MIF in nonalcoholic steatohepatitis. FASEB J 2014;28(12):5136-5147

136 Fosgerau K, Hoffmann T. Peptide therapeutics: current status and future directions. Drug Discov Today 2015;20(01):122-128

137 Lau JL, Dunn MK. Therapeutic peptides: historical perspectives, current development trends, and future directions. Bioorg Med Chem 2018;26(10):2700-2707

138 Henninot A, Collins JC, Nuss JM. The current state of peptide drug discovery: back to the future? J Med Chem 2018;61(04):1382-1414

139 Zorzi A, Deyle K, Heinis C. Cyclic peptide therapeutics: past, present and future. Curr Opin Chem Biol 2017;38:24-29

140 Leman LJ, Maryanoff BE, Ghadiri MR. Molecules that mimic apolipoprotein A-I: potential agents for treating atherosclerosis. J Med Chem 2014;57(06):2169-2196

141 Mallavia B, Recio C, Oguiza A, et al. Peptide inhibitor of NF-KB translocation ameliorates experimental atherosclerosis. Am J Pathol 2013;182(05):1910-1921

142 Hong HY, Lee HY, Kwak W, et al. Phage display selection of peptides that home to atherosclerotic plaques: IL-4 receptor as a candidate target in atherosclerosis. J Cell Mol Med 2008;12 (5B):2003-2014

143 Koenen RR, von Hundelshausen P, Nesmelova IV, et al. Disrupting functional interactions between platelet chemokines inhibits atherosclerosis in hyperlipidemic mice. Nat Med 2009;15(01): 97-103

144 Koenen RR, Weber C. Therapeutic targeting of chemokine interactions in atherosclerosis. Nat Rev Drug Discov 2010;9(02): 141-153

145 Figueiredo CR, Matsuo AL, Massaoka MH, Polonelli L, Travassos LR. Anti-tumor activities of peptides corresponding to conserved complementary determining regions from different immunoglobulins. Peptides 2014;59:14-19

146 Figueiredo CR, Azevedo RA, Mousdell S, et al. Blockade of MIFCD74 signalling on macrophages and dendritic cells restores the 
antitumour immune response against metastatic melanoma. Front Immunol 2018;9:1132

147 Yang L, Liu Z, Ren H, et al. DR $\alpha 1-M O G-35-55$ treatment reduces lesion volumes and improves neurological deficits after traumatic brain injury. Metab Brain Dis 2017;32(05):1395-1402

148 Meza-Romero R, Benedek G, Leng L, Bucala R, Vandenbark AA. Predicted structure of MIF/CD74 and RTL1000/CD74 complexes. Metab Brain Dis 2016;31(02):249-255

149 Offner H, Sinha S, Burrows GG, Ferro AJ, Vandenbark AA. RTL therapy for multiple sclerosis: a Phase I clinical study. J Neuroimmunol 2011;231(1-2):7-14

150 Meza-Romero R, Benedek G, Jordan K, et al. Modeling of both shared and distinct interactions between MIF and its homologue D-DT with their common receptor CD74. Cytokine 2016; 88:62-70

151 Crump MP, Gong JH, Loetscher P, et al. Solution structure and basis for functional activity of stromal cell-derived factor-1; dissociation of CXCR4 activation from binding and inhibition of HIV-1. EMBO J 1997; 16(23):6996-7007

152 Tamamura H, Hori A, Kanzaki N, et al. T140 analogs as CXCR4 antagonists identified as anti-metastatic agents in the treatment of breast cancer. FEBS Lett 2003;550(1-3):79-83

153 DeMarco SJ, Henze H, Lederer A, et al. Discovery of novel, highly potent and selective beta-hairpin mimetic CXCR4 inhibitors with excellent anti-HIV activity and pharmacokinetic profiles. Bioorg Med Chem 2006;14(24):8396-8404

154 Fujii N, Oishi S, Hiramatsu K, et al. Molecular-size reduction of a potent CXCR4-chemokine antagonist using orthogonal combination of conformation- and sequence-based libraries. Angew Chem Int Ed Engl 2003;42(28):3251-3253

155 Ueda S, Oishi S, Wang ZX, et al. Structure-activity relationships of cyclic peptide-based chemokine receptor CXCR4 antagonists: disclosing the importance of side-chain and backbone functionalities. J Med Chem 2007;50(02):192-198

156 Demmer O, Frank AO, Hagn F, et al. A conformationally frozen peptoid boosts CXCR4 affinity and anti-HIV activity. Angew Chem Int Ed Engl 2012;51(32):8110-8113

157 Demmer O, Dijkgraaf I, Schumacher U, et al. Design, synthesis, and functionalization of dimeric peptides targeting chemokine receptor CXCR4. J Med Chem 2011;54(21):7648-7662

158 Di Maro S, Trotta AM, Brancaccio D, et al. Exploring the Nterminal region of $\mathrm{C}-\mathrm{X}-\mathrm{C}$ motif chemokine 12 (CXCL12): identification of plasma-stable cyclic peptides as novel, potent $\mathrm{C}-\mathrm{X}-\mathrm{C}$ chemokine receptor type 4 (CXCR4) antagonists. J Med Chem 2016;59(18):8369-8380

159 Di Maro S, Di Leva FS, Trotta AM, et al. Structure-activity relationships and biological characterization of a novel, potent, and serum stable C-X-C chemokine receptor type 4 (CXCR4) antagonist. J Med Chem 2017;60(23):9641-9652

160 Groß A, Möbius K, Haußner C, Donhauser N, Schmidt B, Eichler J. Mimicking protein-protein interactions through peptide-peptide interactions: HIV-1 gp120 and CXCR4. Front Immunol 2013; 4:257

161 Möbius K, Dürr R, Haussner C, Dietrich U, Eichler J. A functionally selective synthetic mimic of the HIV-1 co-receptor CXCR4. Chemistry 2012;18(27):8292-8295

162 Wang J, Tong C, Yan X, et al. Limiting cardiac ischemic injury by pharmacological augmentation of macrophage migration inhibitory factor-AMP-activated protein kinase signal transduction. Circulation 2013;128(03):225-236
163 Höllriegl W, Bauer A, Baumgartner B, et al. Pharmacokinetics, disease-modifying activity, and safety of an experimental therapeutic targeting an immunological isoform of macrophage migration inhibitory factor, in rat glomerulonephritis. Eur J Pharmacol 2018;820:206-216

164 Sparkes A, De Baetselier P, Brys L, et al. Novel half-life extended anti-MIF nanobodies protect against endotoxic shock. FASEB J 2018;32(06):3411-3422

165 Kaufman JL, Niesvizky R, Stadtmauer EA, et al. Phase I, multicentre, dose-escalation trial of monotherapy with milatuzumab (humanized anti-CD74 monoclonal antibody) in relapsed or refractory multiple myeloma. Br J Haematol 2013;163(04): 478-486

166 Griffiths K, Dolezal O, Cao B, et al. i-bodies, human single domain antibodies that antagonize chemokine receptor CXCR4. J Biol Chem 2016;291(24):12641-12657

167 Korkolopoulou P, Levidou G, El-Habr EA, et al. Expression of interleukin-8 receptor CXCR2 and suppressor of cytokine signaling-3 in astrocytic tumors. Mol Med 2012;18:379-388

168 Crichlow GV, Lubetsky JB, Leng L, Bucala R, Lolis EJ. Structural and kinetic analyses of macrophage migration inhibitory factor active site interactions. Biochemistry 2009;48(01):132-139

169 Rajasekaran D, Zierow S, Syed M, Bucala R, Bhandari V, Lolis EJ. Targeting distinct tautomerase sites of D-DT and MIF with a single molecule for inhibition of neutrophil lung recruitment. FASEB J 2014;28(11):4961-4971

170 Winner M, Meier J, Zierow S, et al. A novel, MIF suicide substrate inhibits motility and growth of lung cancer cells. Cancer Res 2008;68(18):7253-7257

171 Al-Abed Y, Dabideen D, Aljabari B, et al. ISO-1 binding to the tautomerase active site of MIF inhibits its pro-inflammatory activity and increases survival in severe sepsis. J Biol Chem 2005; 280(44):36541-36544

172 Tynan A, Mawhinney L, Armstrong ME, et al. Macrophage migration inhibitory factor enhances Pseudomonas aeruginosa biofilm formation, potentially contributing to cystic fibrosis pathogenesis. FASEB J 2017;31(11):5102-5110

173 Mawhinney L, Armstrong ME, O’ Reilly C, et al. Macrophage migration inhibitory factor (MIF) enzymatic activity and lung cancer. Mol Med 2015;20:729-735

174 Pease J, Horuk R. Chemokine receptor antagonists. J Med Chem 2012;55(22):9363-9392

175 Bizzarri C, Beccari AR, Bertini R, Cavicchia MR, Giorgini S, Allegretti M. ELR + CXC chemokines and their receptors (CXC chemokine receptor 1 and $\mathrm{CXC}$ chemokine receptor 2) as new therapeutic targets. Pharmacol Ther 2006;112(01):139-149

176 Kleemann R, Hausser A, Geiger G, et al. Intracellular action of the cytokine MIF to modulate AP-1 activity and the cell cycle through Jab1. Nature 2000;408(6809):211-216

177 Nguyen MT, Beck J, Lue H, et al. A 16-residue peptide fragment of macrophage migration inhibitory factor, MIF-(50-65), exhibits redox activity and has MIF-like biological functions. J Biol Chem 2003;278(36):33654-33671

178 Liang X. CXCR4, inhibitors and mechanisms of action. Chem Biol Drug Des 2008;72(02):97-110

179 Aboye TL, Ha H, Majumder S, et al. Design of a novel cyclotidebased CXCR4 antagonist with anti-human immunodeficiency virus (HIV)-1 activity. J Med Chem 2012;55(23):10729-10734 